\title{
PENGEMBANGAN PERANGKAT PEMBELAJARAN MATEMATIKA DENGAN STRATEGI THINK TALK WRITE BERBASIS BLENDED LEARNING UNTUK MENINGKATKAN KEMAMPUAN MENULIS MATEMATIK SISWA SMP
}

\author{
Maria C.T Wangge \\ carmelitawangge46@gmail.com
}

\begin{abstract}
Abstrak
Tujuan dari penelitian ini adalah untuk: (1) Menghasilkan perangkat pembelajaran dengan strategi Think Talk Write (TTW) pada materi persamaan dan pertidaksamaan, (2) Mendeskripsikan keefektifan strategi think talk write pada materi persamaan dan pertidaksamaan. Proses pengembangan perangkat pembelajaran menggunakan model ADDIE yang terdiri dari 4 langkah, yaitu: analisis (analysis), perancangan (design), pengembangan (develop), penerapan (implementation) dan evaluasi (evaluation). Hasil pengembangan perangkat pembelajaran berupa Lembar Kerja Siswa (LKS). Berdasarkan hasil analisis deskriptif pada proses pengembangan perangkat pembelajaran, diperoleh perangkat pembelajaran yang baik, yakni perangkat pembelajaran yang memenuhi kriteria valid, praktis dan efektif.

Berdasarkan hasil analisis statistik deskriptif pada penelitian eksperimen, diperoleh kesimpulan bahwa Pembelajaran dengan menggunakan strategi Think Talk Write (TTW) untuk mengajarkan materi persamaan dan pertidaksamaan baik. Hal ini dapat dilihat dari 1) Aktivitas siswa dalam pembelajaran berkategori efektif, 2) Respon siswa terhadap pembelajaran berkategori positif.

Berdasarkan hasil analisis, Pembelajaran dengan menggunakan model ADDIE pada materi persamaan dan pertidaksamaan memperoleh hasil yang baik.
\end{abstract}

Kata-kata kunci : Perangkat Pembelajaran, Pembelajaran Model ADDIE

\begin{abstract}
The aim of this study is to: (1) Produce a learning device with a good Think Talk Write (TTW) Learning approach in comparison, (2) Describe the effectiviness of the Think Talk Write Learning on the rectangle material. Learning device development process using ADDIE model which consists of four steps: analysis, design, development, implementation and evaluation. The result of the learning device development, such as student worksheet (LKS). Based on the result of descriptive analysis on the development of the learning process, abtained a good learning device, namely the device that meets the criteria for a valid, practical, and effective study.
\end{abstract}


Based on the results of the descriptive statistical analysis of the experimental study, we conclude that Think Talk Write Learning was effective to teach rectangle material. It can be seen from 1) the ability of the teacher to manage learning was good category, 2) learning activities were effective category.

Based on the result of analysis, it can be concluded that student learning outcomes follow Think Talk Write (TTW) Learning is better than the result of student who take the conventional mathematic instruction at rectangle material.

\section{Key Words: Mathematics Learning, ADDIE Learning}

\section{PENDAHULUAN}

Pendidikan adalah upaya menciptakan situasi yang membuat siswa mau dan dapat belajar atas dorongan diri sendiri untuk mengembangkan bakat, pribadi, dan potensi-potensi lainnya secara optimal ke arah yang positif (Pidarta, 2013:12). Dengan demikian, pendidikan mempunyai peran yang sangat penting dalam meningkatkan kualitas sumber daya manusia dan upaya mewujudkan cita-cita bangsa Indonesia dalam mewujudkan kesejahteraan umum dan mencerdaskan kehidupan bangsa. Untuk meningkatkan kualitas pendidikan tersebut, perlu adanya pembaruan di bidang pendidikan. Salah satu wujud pembaruan pendidikan adalah peningkatan kualitas kemampuan pedagogik guru. Wujud nyata dari kompetensi tersebut adalah kemampuan guru dalam mengembangkan perangkat pembelajaran.

Matematika merupakan salah satu mata pelajaran yang diberikan di jenjang pendidikan dasar dan menengah. Matematika yang diberikan dijenjang persekolahan tersebut disebut matematika sekolah. Sebagai salah satu ilmu dasar, matematika perlu diberikan mulai dari pendidikan dasar untuk membekali siswa dengan kemampuan berpikir logis, analistis, sistematis, kritis, kreatif dan kemampuan untuk bekerja sama (Depdiknas 2006).
Menurut Soedjadi (2000: 101), kemampuan guru merencanakan dan melaksanakan pembelajaran matematika dengan baik merupakan hal yang penting. Ini berarti sebelum mengajar, guru perlu membuat perencanaan pembelajaran agar Untuk mencapai tujuan pembelajaran yang baik perlu dipikirkan penyajian dan suasana pembelajaran matematika yang membuat anak merasa senang belajar matematika. Soedjadi (2000:201) mengatakan betapapun tepat dan baik bahan ajar matematika yang ditetapkan belum menjamin akan tercapai tujuan pendidikan matematika yang diinginkan. Ini berarti proses pembelajaran yang dilaksanakan merupakan salah satu faktor yang penting untuk mencapai tujuan pendidikan.

Pembelajaran matematika merupakan kegiatan pendidikan yang menggunakan matematika sebagai upaya untuk mencapai tujuan yang ditetapkan (Soedjadi, 2000:6). Matematika sebagai wahana pendidikan tidak hanya digunakan untuk mencapai satu tujuan, misalnya mencerdaskan siswa, tetapi dapat pula untuk membentuk kepribadian siswa serta mengembangkan keterampilan tertentu. Hal ini mengarahkan perhatian siswa kepada pembelajaran nilai-nilai dalam kehidupan melalui matematika.

Guru sebagai salah satu sumber belajar berkewajiban menyediakan lingkungan belajar yang kreatif bagi kegiatan belajar siswa di kelas. Cara 
penyajian materi yang tidak tepat atau suasana pembelajaran yang tidak menyenangkan dapat menjadi salah satu sumber kesulitan siswa dalam belajar. Kebiasaan yang selama ini sering terjadi di kelas, yaitu proses pembelajaran di sekolah disajikan oleh guru dengan memberikan definisi dan rumus secara langsung, siswa diberikan contoh-contoh dengan penyelesainnya, setelah itu diberikan latihan soal dan dibahas secara bersama-sama. Selain itu, siswa biasanya dituntut untuk menerima apa yang dianggap penting oleh guru dan menghafalnya sehingga banyak siswa yang tahu atau hafal materi pelajaran tetapi tidak mampu mengaplikasikan pengetahuannya bagi peningkatan kualitas kehidupan.

\section{METODE}

Untuk menjawab pertanyaan penelitian, maka penelitian ini termasuk jenis penelitian pengembangan perangkat karena dalam penelitian ini dikembangkan perangkat pembelajaran matematika realistik pada materi persamaan dan pertidaksamaan di kelas VII SMP. Perangkat pembelajaran yang dimaksud Lembar Kegiatan Siswa (LKS). Pengembangan perangkat mengacu pada model ADDIE yang dikemukakan oleh Reiser dan Mollenda (Amri, 2013:264).

Model pengembangan ADDIE muncul pada tahun 1990-an yang dikembangkan oleh Reiser dan Mollenda (Amri, 2013:264). Salah satu fungsinya yaitu menjadi pedoman dalam membangun perangkat program pelatihan yang efektif, dinamis dan mendukung kinerja pelatihan itu sendiri. Model ini menggunakan lima tahap pengembangan, yaitu:

\section{Analysis (Analisis)}

Analisis merupakan tahap pertama yang harus dilakukan oleh seorang pengembang pembelajaran. Kaye Shelton dan George Saltsman dalam Amri (2013:264) menyatakan bahwa ada tiga segmen yang harus dianalisis yaitu siswa, pembelajaran, serta media untuk menyampaikan bahan ajarnya. Sedangkan menurut Pribadi (2009:128) langkah analisis terdiri atas dua tahap, yaitu analisis kinerja dan analisis kebutuhan.

Analisis kinerja dilakukan untuk mengetahui dan mengklarifikasi apakah masalah kinerja yang dihadapi memerlukan solusi berupa penyelenggaraan program pembelajaran. Sedangkan analisis kebutuhan merupakan langkah yang diperlukan untuk menentukan kemampuankemampuan atau kompetensi yang perlu dipelajari oleh siswa untuk meningkatkan kinerja atau prestasi belajar. Hal ini dapat dilakukan apabila pembelajaran dianggap sebagai solusi dari masalah pembelajaran yang sedang dihadapi.

Menurut Pribadi (2009:129) ada dua pertanyaan kunci yang harus dicari jawabannya oleh seorang perancang program pembelajaran pada saat melakukan tahap analisis. Pertama, apakah siswa memerlukan tujuan pembelajaran yang telah ditentukan? Kedua, apakah siswa dapat mencapai tujuan pembelajaran yang telah ditentukan?

\section{Design (Desain)}

Pada tahap ini diperlukan pembelajaran yang didesain sehingga program tersebut dapat mencapai tujuan pembelajaran seperti yang diharapkan. Amri (2013:264) menyatakan bahwa langkah-langkah dalam tahapan ini adalah membuat silabus yang didalamnya termasuk: memilih standar kompetensi, menentukan kompetensi dasar, menentukan indikator keberhasilan, memilih bentuk penilaian, menentukan sumber atau bahan-bahan belajar, menerapkan strategi 
pembelajaran, membuat storyboard, mendesain antar muka.

Pada tahap desain, pusat perhatian perlu difokuskan pada upaya untuk menyelidiki masalah pembelajaran yang sedang dihadapi. Hal ini merupakan inti dari langkah analisis, yaitu mempelajari masalah dan menemukan alternatif solusi yang akan ditempuh untuk dapat mengatasi masalah pembelajaran yang berhasil diidentifikasi melalui langkah analisis kebutuhan.

Langkah penting yang perlu dilakukan dalam desain adalah menentukan pengalaman belajar yang perlu dimiliki oleh siswa selama mengikuti aktivitas pembelajaran. Langkah desain harus mampu menjawab pertanyaan apakah program pembelajaran yang didesain dapat digunakan untuk mengatasi masalah kesenjangan performa yang terjadi pada diri siswa. Kesenjangan kemampuan yang dimaksud dalam hal ini adalah perbedaan yang dapat diamati antara kemampuan yang telah dimiliki dengan kemampuan yang seharusnya dimiliki oleh siswa.

Menurut Pribadi (2009:131) pertanyaan-pertanyaan kunci yang harus dicari jawabannya oleh perancang program pembelajaran pada saat melakukan tahap desain adalah sebagai berikut.

a. Kemampuan atau kompetensi khusus seperti apa yang harus dimiliki oleh siswa setelah menyelesaikan program pembelajaran?

b. Indikator apa yang dapat digunakan untuk mengukur keberhasilan siswa dalam mengikuti program pembelajaran?

c. Peralatan atau kondisi bagaimana yang diperlukan oleh siswa agar dapat melakukan unjuk kompetensi setelah mengikuti program pembelajaran?

d. Bahan ajar dan kegiatan seperti apa yang dapat digunakan dalam mendukung program pembelajaran?

\section{Development (Pengembangan)}

Tahapan ini merupakan tahapan produksi di mana segala sesuatu yang telah dibuat dalam tahapan desain menjadi nyata. Langkah pengembangan meliputi membuat dan memodifikasi bahan ajar untuk mencapai tujuan pembelajaran. Pengadaan bahan ajar perlu disesuaikan dengan tujuan pembelajaran spesifik yang telah dirumuskan oleh desainer atau perancang program pembelajaran dalam langkah desain. Langkah pengembangan dengan kata lain mencakup kegiatan memilih dan menentukan metode, media, serta strategi pembelajaran yang sesuai untuk digunakan dalam menyampaikan materi pembelajaran.

Menurut Pribadi (2009:133) ada dua tujuan penting yang perlu dicapai dalam melakukan pengembangan, yaitu:

a. Memproduksi atau merevisi bahan ajar yang akan digunakan untuk mencapai tujuan pembelajaran yang telah dirumuskan sebelumnya.

b. Memilih media atau kombinasi media terbaik yang akan digunakan untuk mencapai tujuan pembelajaran.

\section{Implementation (Penerapan)}

Pada tahapan ini sistem pembelajaran sudah siap untuk digunakan oleh pembelajar. Kegiatan yang dilakukan dalam tahapan ini adalah mempersiapkan dan memasarkannya ke target pembelajar. Tujuan utama dari langkah ini antara lain membimbing siswa untuk mencapai tujuan atau kompetensi, menjamin terjadinya pemecahan masalah atau solusi untuk 
mengatasi kesenjangan hasil belajar yang dihadapi oleh siswa dan memastikan bahwa pada akhir program pembelajaran, siswa perlu memilki kompetensi pengetahuan dan keterampilan yang diperlukan.

$$
\text { Pertanyaan-pertanyaan }
$$

kunci yang harus dicari jawabannya oleh perancang program pembelajaran pada saat melakukan tahap implementasi (Pribadi, 2009:135) yaitu:

a. Metode pembelajaran seperti apakah yang paling efektif untuk digunakan dalam menyampaikan bahan atau materi pembelajaran?

b. Upaya atau strategi apa yang dapat dilakukan untuk menarik dan memelihara minat siswa agar tetap mampu memusatkan perhatian penyampaian terhadap pembelajaran materi disampaikan?

\section{Evaluation (Evaluasi)}

\section{HASIL DAN PEMBAHASAN}

Secara garis besar tujuan penelitian ini adalah mendeskripsikan proses pengembangan perangkat sehingga menghasilkan perangkat pembelajaran yang baikn pada materi persamaan dan pertidaksamaan kelas VII SMP serta memberikan gambaran tentang keefektifan pembelajaran menggunakan pembelajaran think talk write dan melihat peningkatan hasil belajar siswa pada materi persamaan dan pertidaksamaan.

Perangkat pembelajaran yang dikembangkan dalam penelitian ini adalah Lembar Kerja Siswa (LKS),. Pengembangan perangkat pembelajaran think talk write pada materi persamaan dan pertidaksamaan kelas VII SMP telah melalui serangkaian tahap pengembangan perangkat model ADDIE yaitu.

\section{Tahap Aanalisis (Analysis)}

Proses pembelajaran matematika di kelas VII SMP Satap III So'a cenderung didominasi oleh guru. Guru menjelaskan materi dengan cara ceramah, sedangkan siswa hanya mendengar dan mencatat
Tahapan evaluasi dapat didefinisikan sebagai sebuah proses yang dilakukan untuk memberikan nilai terhadap program pembelajaran. Terdapat dua macam evaluasi, yaitu evalusi formatif dan evaluasi sumatif. Evaluasi formatif dapat berlangsung pada setiap tahapan. Misalnya pada tahap analisis, evaluasi formatif dilaksanakan dengan cara melakukan klarifikasi terhadap kompetensi pengetahuan siswa setelah mengikuti program pembelajaran. Sedangkan evaluasi sumatif dilakukan setelah tahapan implementasi dan dievaluasi secara formatif dan direvisi sesuai dengan standar yang digunakan oleh perancang. Evaluasi digunakan untuk mengetahui keefektifan pembelajaran. apa yang dipaparkan oleh guru. Kalaupun ada proses tanya jawab antara guru dan siswa, itu hanya bagian kecil dari keseluruhan proses pembelajaran.

Dalam menyampaikan materi, guru sangat jarang mengaitkan materi dengan kehidupan sehari-hari yang dekat dengan siswa. Akibatnya siswa merasa belajar matematika tidak ada manfaatnya. Begitu juga dalam menyelesaikan soalsoal, guru lebih banyak memberikan petunjuk cara menyelesaikan soal dan mengulang-ulangnya. Dalam menyelesaikan soal setipe, siswa hanya menirukan cara guru tersebut. Hal ini menyebabkan siswa cenderung pasif dalam belajar.

Salah satu alternatif pembelajaran matematika yang mengaitkan pengalaman kehidupan nyata siswa dengan materi serta dapat memberi bekal kompetensi yang memadai baik untuk studi lanjut maupun untuk memasuki dunia kerja adalah pembelajaran matematika realistik. Dalam melaksanakan pembelajaran 
matematika realistik diperlukan perangkat pembelajaran yang sesuai.

a. Analisis Tugas

Analisis tugas dilakukan untuk mengidentifikasi berbagai keterampilan akademis yang harus dikuasai siswa dan tugas-tugas yang akan dikerjakan siswa sesuai dengan analisis materi. Hasil akhir analisis tugas adalah tertuang dalam Lembar Kerja Siswa (LKS) sebagai perangkat pembelajaran.

\section{Tahap Perancangan (Design)}

Berdasarkan hasil kajian dari fase analysis, selanjutnya dilakukan kajian mengenai garis besar identifikasi rancangan perangkat pembelajaran yang akan dikembangkan. Kajian ini terdiri dari:

a. Pemilihan Media

Dalam pelaksanaan pembelajaran think talk write pada materi persamaan dan pertidaksamaan di kelas VII SMP Satap III So'a menggunakan media papan tulis dan lembar kerja Siswa (LKS). Pada setiap pertemuan, masing-masing siswa menerima seperangkat LKS yang membantu siswa untuk memahami masalah kontekstual, menyelesaikan masalah kontekstual, membandingkan dan mendiskusikan jawaban dan menyimpulkan.

b. Perancangan Awal Perangkat Pembelajaran

Kegiatan utama dalam tahap perancangan adalah penulisan perangkat pembelajaran dan instrumen penelitian. Pada tahap ini dihasilkan rancangan awal dari Lembar Kerja Siswa (LKS). Pada tahap ini juga dihasilkan lembar angket respon siswa terhadap pembelajaran think talk write.

3. Tahap Pengembangan (Develop)

Tujuan tahap ini adalah untuk menghasilkan perangkat pembelajaran think talk write yang sudah direvisi berdasarkan saran para ahli (validator).

\section{a. Hasil Validasi Perangkat Pembelajaran \\ Perangkat pembelajaran yang} dikembangkan yaitu LKS divalidasi oleh 2 orang validator.

\begin{abstract}
KESIMPULAN
Berdasarkan pembahasan hasil penelitian dengan menggunakan model ADDIE materi persamaan dan pertidaksamaan, maka dapat diambil kesimpulan sebagai berikut:
\end{abstract}

Pembelajaran dengan menggunakan model ADDIE pada materi persamaan dan pertidaksamaan memperoleh hasil yang baik.

\section{SARAN}

Berdasarkan hasil penelitian ini, beberapa saran yang dapat peneliti kemukakan sebagai berikut:

1. Pembelajaran ADDIE dapat digunakan sebagai perangkat pembelajaran alternatif oleh guru untuk mengajar materi persamaan dan pertidaksamaan.

2. Jika penelitian lain tertarik untuk melakukan penelitian-penelitian yang serupa, maka perlu meminimalisasi kelemahan-kelemahan dalam penelitian ini.

\section{DAFTAR PUSTAKA}

Ahmadi, K. (2011) Strategi Pembelajaran Sekolah Terpadu. Jakarta: Prestasi Pustaka.

Arikunto, S. (2012). Dasar-dasar Evaluasi Pendidikan. Jakarta: Bumi Aksara.

Daryanto \& Dwicahyono, A. (2014). Pengembangan Perangkat Pembelajaran (Silabus, RPP, PHB, Bahan Ajar). Yogyakarta: Gava Media.

Eggen, P. D., \& Kauchack, D. P. (2015). Strategies for Teachers: Teaching Content and Thinking Skills. Boston: Allyn and Bacon.

Hamdani. (2011). Strategi Belajar Mengajar. Bandung: Pustaka Setia.

Hobri. (2010). Metodologi Penelitian Pengembangan. Jember: Pena Salsabila.

Joyce, B., Weil, M \& Calhoun, E. (1992). Models of Teaching, $5^{\text {th }}$ Edition. USA: Allyn and Bacon. 
Kyriacou, C. (2009). Effective Teaching: Theory and Practice. Bandung: Nusa Media. Penerjemah: M. Khozim.

Majid, A. (2005). Perencanaan Pembelajaran, Mengembangkan Standar Kompetensi Guru. Bandung: PT Remaja Rosdakarya..

Muslich, M. (2008). Kurikulum Tingkat Satuan Pendidikan, cetakan keempat. Jakarta: Bumi Aksara.

Pribadi, B. A. (2009). Model Desain Sistem Pembelajaran. Jakarta: PT Dian Rakyat.

Purwanto. (2004). Pendekatan Inovatif Instructional System Design (ADDIE Model) dalam Perancangan dan Pengembangan Bahan Ajar. Jakarta: Pusat Teknologi Komunikasi dan Infomasi Pendidikan.
Ratumanan, T. G. (2004). Belajar dan Pembelajaran. Surabaya: Unesa University Press.

Sanjaya, W. (2008). Perencanaan dan Desain Sistem Pembelajaran. Jakarta: Prenada Media Group.

Schunk, D .H. (2012). Learning Theoris. Jakarta: Pustaka Pelajar.

Skemp, R. R. (1987). The Psychology of Learning Mathematics. New Jersey: Lawrence Erlbraum Associates Publisher. 